\title{
Chapter Headings of
}

\section{THE PERFECT WISDOM IN 18,000 LINES}

1. Introduction

Nar.

2. The production of the

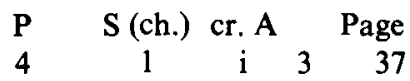
thought of enlighten-

$$
\text { ment }
$$

$16 \mathrm{~b}$
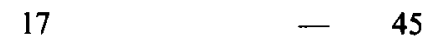

3. Observations

4. Equal to the unequalled

5. The tongue

6. Subhūti

$89 \mathrm{a}$

95

-85
$-\quad 87$

7. Entrance into the certainty of salvation

$107 \mathrm{a}$

98

-87
$-\quad 89$

\begin{tabular}{l}
3 \\
\hline
\end{tabular}

8. Srenika, the Wanderer

$116 \mathrm{a}$

116

123

9. The sign

$136 \mathrm{~b}$

139

$151 \mathrm{a}$

150

$173 a$

160

11. Similes

$188 \mathrm{a}$

172

13. The six perfections

$192 a$

175

14. Neither bound nor freed

209a

185

$225 a$

194

244a 203

2

595

$\begin{array}{ll}7 & 99\end{array}$

$\begin{array}{ll}11 & 104\end{array}$

$16 \quad 111$

$\begin{array}{ll}17 & 117\end{array}$

$18 \quad 126$

$20 \quad 128$

15. The Concentrations

16. Entrance into the dhārani-doors

17. The preparations for the stages

$262 b$

214

20

137

$23 \quad 143$

18. Going forth on the stages of the great vehicle

280a 225<smiles>C1CCCCC1</smiles>

$\begin{array}{ll}23 & 179\end{array}$

19. Surpassing

295b 231

$325 \mathrm{a} \quad 242$

11

$24 \quad 182$

20. Nonduality

$353 \mathrm{~b} \quad 256$

$\begin{array}{ll}25 & 188\end{array}$

21. Subhūti, the Elder

$374 \mathrm{a} \quad 200 \mathrm{~b}$

$\begin{array}{ll}27 & 194\end{array}$

22. The first Śakra-chapter

391a 208a

$397 \mathrm{a} \quad 211 \mathrm{~b}$

12,13

$33 \quad 203$

23. 'Hard to fathom'

24. Infinite

25. The second Śakrachapter

$414 a \quad 219 b$

$39 \quad 211$

$41 \quad 214$

16

48

220 
26. Gains

27. The shrine

28. The proclamation of a Bodhisattva's qualities

29. The heretics

30. The advantages of bearing in mind and reverence

31. On relics

32. The distinction of merit

33. On dedication and rejoicing

34. Glorification of the virtues of consummation

35. The Hells

36. The exposition of the purity of all dharmas

37. Unsupported anywhere

38. Without basis

39. The tradition in the North

40. Mara

41. The absence of Mara's hosts

42. Showing the world

43. Unthinkable

44. The congregation

45. The ship

46. Exposition of the ownbeing of all dharmas

47. The disciplining of greed

48. Settlement in the training of a Bodhisattva

49. Irreversibility

50. Exposition of the tokens of irreversibility
Nar. $\quad P$

$420 \mathrm{~b} \quad 223 \mathrm{a}$

$434 \mathrm{a} 230 \mathrm{~b}$

S (ch.) cr. A Page

$17 \quad$ iii $51 \quad 224$

$\begin{array}{lll}18 & 54 & 229\end{array}$

$\begin{array}{lllll}449 \mathrm{~b} & 239 \mathrm{a} & 19 & 70 & 236\end{array}$

$\begin{array}{lllll}457 \mathrm{a} & 241 \mathrm{~b} & 20 & 76 & 240\end{array}$

$\begin{array}{lllllll}460 b & 242 a & 21 & & 80 & 243 \\ 471 b & 243 d & 22 & \text { iv } & 94 & 249\end{array}$

$\begin{array}{llllll}499 b & 249 b & 23 & \text { v } & 104 & 259\end{array}$

$\begin{array}{llllll}510 \mathrm{a} & 258 \mathrm{a} & 24 & \text { vi } & 135 & 269\end{array}$

V. II

$\begin{array}{llllll}23 \mathrm{~b} & 270 \mathrm{a} & 25 & \text { vii } & 170 & 283\end{array}$

$\begin{array}{lllll}34 a & 273 b & 26 & 176 & 287\end{array}$

$\begin{array}{llllll}47 \mathrm{~b} & 279 \mathrm{~b} & 27 & \text { viii } & 187 & 295\end{array}$

$\begin{array}{lllll}61 \mathrm{~b} & 286 \mathrm{a} & 28 & 193 & 302\end{array}$

$\begin{array}{llllll}80 \mathrm{~b} & 297 \mathrm{a} & 29 & \text { ix } & 205 & 312\end{array}$

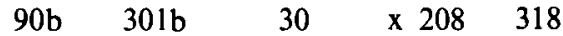

$\begin{array}{lllll}122 b & 315 a & 31 & x i & 232\end{array}$

$\begin{array}{lllll}132 b & 319 b & 32 & 243 & 338\end{array}$

$146 \mathrm{a} 328 \mathrm{a} \quad$ xii $252 \quad 346$

$\begin{array}{lllll}158 \mathrm{~b} & 333 \mathrm{a} & 33 & 272 & 351\end{array}$

$170 \mathrm{~b} \quad 336 \mathrm{~b} \quad 34 \quad$ xiii $280 \quad 358$

$179 \mathrm{~b} \quad 343 \mathrm{a} \quad 35 \quad$ xiv $286 \quad 363$

$\begin{array}{llllll}187 b & 348 a & 36 & \text { xv } & 292 & 367\end{array}$

$\begin{array}{lllll}199 a & 356 a & 37 & 299 & 372\end{array}$

$\begin{array}{lllll}206 a & 361 \text { a } & 38 & 303 & 376\end{array}$

$\begin{array}{llllll}231 a & 377 a & 39 & \text { xvii } & 323 & 388\end{array}$

$\begin{array}{lllll}243 a & 383 b & 40 & 331 & 396\end{array}$ 
51. The exposition of skill in means

52. The fulfilment of skill in the six perfections

53. The prediction of the Ganges Goddess

54. Demonstration of the development of skill in means

55. The exposition of the forsaking of discrimination

56. Even training

57. Practices

58. Exposition of nondiscrimination through similes

59. Nonattachment

60. Entrusting

61. Nonextinction

62. The supreme attainment

63. Many questions concerning the duality of dharmas

64. Right exposition

65. The skill in honouring, tending, and revering the good friends

66. Exposition of skill in means

67. Morality

68. Growth

69. Exposition of the path development

70. The exposition of the consummation of the training in gradual activity

71. The nature of dharmas is signless and cannot be apprehended
Nar.

$$
\text { P }
$$

S (ch.) cr. A

Page

$\begin{array}{lllll}255 a & 390 a & 41 & \text { xviii } 341 \quad 404\end{array}$

$272 b \quad 398 b$

$42 \quad x i x \quad 356$

415

$287 b \quad 404 b$

43

365

422

291a 406a

$\begin{array}{lll}44 \quad x \times & 370\end{array}$

424

$301 \mathrm{~b} \quad 412 \mathrm{a}$

45

380

431

$324 \mathrm{~b} \quad 421 \mathrm{a}$

$46 \quad x x i i i \quad 410$

447

$335 \mathrm{a} \quad 425 \mathrm{a}$

$47 \quad x x v 424$

453

$343 a \quad 428 b$

$48 \quad$ xxvi $434 \quad 458$

$354 \mathrm{~b} \quad 430 \mathrm{~b}$

49 xxvii $444 \quad 462$

$364 a \quad 445 a$

$454 \quad 481$

$378 \mathrm{~b} \quad 451 \mathrm{~b}$

50

490

$385 \mathrm{~b} \quad 455 \mathrm{a}$

52

494

436b-

$445 \mathrm{a}$

$403 \mathrm{a} \quad 465 \mathrm{~b}$

53

505

$445 b \quad 479 b$

54

524

$455 b \quad 484 b \quad 55$

530

$460 \mathrm{~b} \quad 487 \mathrm{~b} \quad 56$

533

$462 b \quad 488 a \quad 57$

535

$462 \mathrm{~b} \quad 488 \mathrm{~b} \quad 58$

536

$463 b \quad 490 a \quad 59$

537

482b 501b

60

547

$496 a \quad 508 b$

61 
72. Exposition of markNar. P S (ch.) cr. A Page lessness

$514 b \quad 517 a \quad 62$ 565

73. The perfection of the imperishable consummation of the marks and minor characteristics

$528 \mathrm{a} \quad 523 \mathrm{~b} \quad 63$

573

V. III

74. The exposition of the sameness of all dharmas $540 \mathrm{~b}$

64

591

75. The exposition of imperturbability

$41 \mathrm{a} \quad 548 \mathrm{~b} \quad 65$

598

76. The armour (put on) for the sake of maturing beings

$6 l b \quad 558 a \quad 66$

607

77. The cognition of the perfect purity of the Buddha-field

$78 \mathrm{a} \quad 565 a$

78. Skill in means in the purification of the Buddha-field

$90 \mathrm{~b} \quad 570 \mathrm{~b}$

68

621

79. Exposition of the nonexistence of own-being

80. The absence of (all) defilement and purification

$108 b \quad 583 b \quad 70$

81. Being joined to ultimate reality

$115 a \quad 586 a$

636

82. The exposition of the unalterable nature of Dharma

$127 \mathrm{~b} \quad 592 \mathrm{a}$

72

642

83. The manifestation of

a Bodhisattva's training

$130 \mathrm{a} \quad 578 \mathrm{a}$

644 